\title{
BOOK REVIEW: PATRIARCHIALISM AT MERRY RIANA BIOGRAPHY BOOK
}

\author{
Fanny Lesmana $^{1 *}$ and Asthararianty ${ }^{2 *}$ \\ ${ }^{1}$ Communication Science, Petra Christian University, Indonesia \\ ${ }^{2}$ Visual Communication Design Science, Petra Christian University, Indonesia
}

\begin{abstract}
As a motivator, Merry Riana gives words of reinforcement to her audience. She is the only one female motivator among 10 top motivators in Indonesia, and she is the only motivator who had biography books. This study focuses on how the characters of Merry Riana as a motivator is represented by the authors of the books. The method that used in this research is Barthes's semiotic with qualitative approach. Authors only look at the text of the book that includes the use of sentences or choice of words by the author. The results of this study show that Merry Riana as a motivator is described as a person who has a strong self-confidence but still needs a husband to help her for making a several decision in her life. It looks that patriachialism still influencing in this book.
\end{abstract}

Keywords: biography's book, motivator, patriarchialism, Barthes's semiotics

\section{Introduction}

Book is a window to the world. That expression is often stated by many people. It means that by reading a book, the reader will get a lot of information needed in life.

By all means, it depends on what type of book the reader reads and also the needs of the reader while reading the book. Surely, book is a medium that provides information. However, the function of book is not only an information provider but also as a medium of entertainment. Book can be a means of relaxation for some people because, in terms of characteristics, book is the first mass media which is also a media that is personal (Baran, 2012, page 83). From its first publication, book became the primary means of spreading and devoting knowledge, as well as became a massive artistic expression and diversion of thought (Danesi, 2010, p 75).

One type of book that is pretty much in demand is a biography. In Baran (2012, p. 101), biography falls into the category of Trade Books. Biography can be called as an institution of social and cultural change. The reason for this is in the biography, the author notes the actions performed by the figures and gives an interpretation of the history inscribed by those figures (Danesi, 2012, p. 176). According to Dewi (2013), biography is one of the most important reading materials because in the biography a figure's life journey from birth to death and the secret of the figure's success are accounted, so the reader can be motivated. In the biography, the reader may discover impressive things of the figure's life journey, take an outlook at the things that can be taken as an example from the figure, look for the figure's privileges and so on.

Merry Riana is one of the motivators who is considered quite influential in Indonesia. Based on motivasiindonesia.net, a network site that makes a list of 10 best and famous motivators in Indonesia (accessed 6 November 2016), Merry Riana is the only female motivator among 9 other motivators, namely Mario Teguh, Christian Adrianto, Andrie Wongso, Tung Desem Waringin, Iphho Santosa, Bong Chandra, Ary Ginandjar, Father Edi and Deddy Corbuzier. They generally convey their motivation verbally. Some of them have published their motivational books. Interestingly, of all the mentioned motivators, only Merry Riana publishes her biography.

The two of Merry Riana's biographies are "Mimpi Sejuta Dollar" written by Albertine Endah (2011) and "Langkah Sejuta Suluh" written by Clara Ng (2014). As biographical books, these two books tell a story of Merry Riana's life journey in achieving her success. As stated by Suwarno (2014), biography is a revelation of a 
person's life derived from memory, written or orally. Both of these books are biographies because they narrate Merry Riana's life.

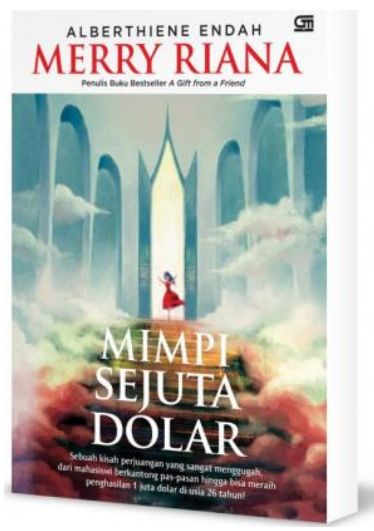

Figure 1. Mimpi Sejuta Dollar Book Cover

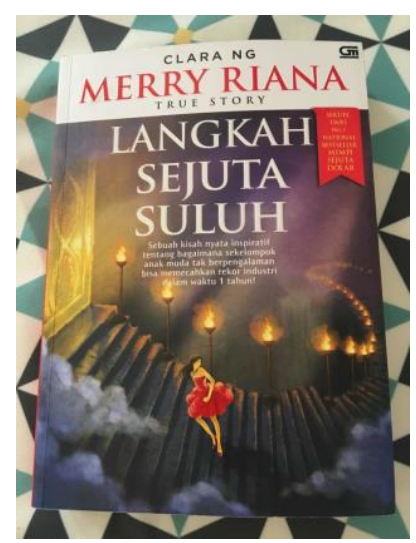

Figure 2. Langkah Sejuta Suluh Book Cover

A person is called a motivator because he/she gives reinforcement as well as inspiration to the people who become his/her audience. Similarly, Merry Riana also gives words of reinforcement to her audience. Therefore, it is possible that the audience or the wider community also expect a perfect life in accordance with the words she conveys. Does a motivator not have a difficult time in her life? How does she overcome those difficult moments? The audience certainly cannot always follow the daily life of the motivator, in this case, is Merry Riana. But, her daily life can be seen in her biography books.

These two books were written by two different authors, Albertine Endah and Clara Ng. Both are professional writers who have different styles of writing and genre. Albertine Endah is known as a biographical author. Some of the biography books that she has written are Chrisye, Krisdayanti and Anne Avantie. Clara $\mathrm{Ng}$ is better known as a novelist. The different genres of the two authors are interesting to be examined in seeing the figure of Merry Riana.

Therefore, this study wants to see how the figure of Mary Riana is represented in her biographies. The subject of this study is book text. The study focuses on authors' texts or words choices.

Research that focuses on biography as a subject is not much conducted and found. One of them is a research conducted by Marsinta Dewi in 2013. However, the research conducted by Marsinta Dewi focused more on applying one of the methods done by high school students in reading a biography with the quasi-experimental method. While, the research conducted this time is a study that is focused on biography as a subject with text analysis as the research method, namely semiotics initiated by Roland Barthes. 
In 2017, a research was conducted on Merry Riana's biography by Asthararianty and Fanny Lesmana. The research was entitled Hermeneutics Studies on Representation of Merry Riana on Her Biography Cover Design. This research was limited to the cover design of both books with Gadamer's hermeneutics method. The result of this study was to show that a female motivator, Merry Riana illustrated in the cover design of the book, is a brave woman who fights to reach the peak of her success.

The research on the book was also done by Hidayat (2014) who uses semiotic analysis on the photo in Erik Prasetya's book "Jakarta Estetika Banal." However, there is a distinction between this research with Hidayat's research. That is, this research examines the entire text of the books.

\section{Discussion}

Mimpi Sejuta Dolar (MSD) book tells the struggle of Merry Riana who started her career as a young entrepreneur in Singapore. The story of her meeting with Alva, her husband, became a sweetener in the story which was narrated by Albertine Endah. Meanwhile, Langkah Sejuta Suluh (LSS) tells how Merry Riana struggled to live his life as a beginner businessman in the field of financial consultants in Singapore.

Both Mimpi Sejuta Dolar (MSD) and Langkah Sejuta Suluh (LSS) books use the first person pronoun. Here, two authors use 'I' to describe the figure of Merry Riana. The pronoun 'I' is not widely used in biography. In general, biography uses the third person pronoun, that is the name of person who is written. For example, the book entitled "Tidak Ada yang Tidak Bisa" by Dahlan Iskan. This book tells the story about a CEO of Bank NISP, Karmaka Surjaudaja. Yet, there are biographies that use the first person 'I' as well, such as Nick Vujicic's biography, a motivator figure from Australia, entitled "Life without Limits". This is different from MSD and LSS books, since the book is written by Nick Vujicic himself.

The word 'I' shows the closeness between a figure in a biography with his readers. The figure directly shows every process in themselves to the reader. Thus, the figure shows the exemplary or things that inspire the reader.

Tahun 1996 Karmaka sudah divonis segera mati. "Salah satu dokter terbaik di dunia dari Amerika Serikat untuk penyakit liver mengatakan saya menderita penyakit liver yang mematikan, yang sangat terlambat saya ketahui," katanya.

Memang Karmaka sudah berusaha maksimal untuk mengatasinya. "Saya sudah keliling rumah sakit terbaik di dunia. Sudah menemui dokter ahli liver di berbagai negara. Tapi semuanya mengatakan saya tidak mungkin bisa diselamatkan lagi," ujar Karmaka.

Satu-satunya jalan yang masih memberikan sedikit kemungkinan hidup hanyalah transplantasi liver. "Tapi saya tidak mau melakukannya," ujar Karmaka. Mengapa? Pada waktu itu, 12 tahun yang lalu, transplantasi liver masih merupakan hal yang baru. Belum semaju sekarang.

Figure 3. Quotation from "Tidak Ada yang Tidak Bisa" that shows the person who is written uses third person pronoun 


\section{Introduction}

M

name is Nick Vujicic (pronounced Voy-a-chich). I am twentyIseven years old. I was born without any limbs, but I am not constrained by my circumstances. I travel the world encouraging millions of people to overcome adversity with faith, hope, love, and courage so that they may pursue their dreams. In this book I will share with you my experiences in dealing with adversity and obstacles, some of them unique to me but most universal to us all. My goal is to encourage you to overcome your own challenges and

Figure 4. Quotation from "Life without Limit" that shows the person who is written uses first person pronoun

MSD story begins with a situation that describes the success of Merry Riana. The presence of Alva, her husband, is described in the first paragraph, in the Prologue. The statement 'Mercedes hitam milik kami' is a statement that wants to show the success of Merry Riana. Although the car series is not mentioned, the fourwheeled vehicle branded Mercedes shows the prosperity of the owner. Victor Mahrizal (2012) once wrote, "Generally speaking, publics are well known, Mercedes-Benz is a brand of the finest luxury cars from Germany that symbolize prosperity and wealth, strength and endurance and endless innovation."

MSD describes the success of Merry Riana in her business manifestly displayed in numbers. "Aku menjadi Merry Riana, anak muda berpenghasilan lebih dari 1 juta dolar, dalam usia 26 tahun (I became Merry Riana, a youth earning over a million dollars, at the age of 26)" (Endah, p 12). It does not explain what country of the currency listed. Yet, the word 'dollar' already describes a success. The dollar referred to in this book is the currency of Singapore. In 2007, when Merry Riana was published as a youth earning 1 million dollars, the Singapore dollar average exchange rate against rupiah was 6,502 rupiah. If she earns 1 million dollars, then in rupiah, Merry Riana has generated about 6.5 billion rupiahs. 


\begin{tabular}{|c|c|c|c|c|c|c|c|c|c|c|c|c|c|c|c|c|}
\hline \multirow{2}{*}{ Mata Uang Asing } & \multicolumn{16}{|c|}{ Kurs Tengah Beberapa Mata Uang Asing Terhadap Ruplah di Bank Indonesia dan Harga Emas dij Jakarta (Rupiah) } \\
\hline & 2000 & 2001 & 2002 & 2003 & 2004 & 2005 & $2006 \quad 1$ & 2007 & 2008 & 2009 & 2010 & 2011 & 2012 & 2013 & 2014 & 2015 \\
\hline Dollar Australian & 5.318 & 5.309 & 5.065 & 6.347 & 7.242 & 7.207 & 7.133 & 8.229 & 7.556 & 8.432 & 9.143 & 9.203 & 10.025 & 10.876 & 10.218 & $10.064,16$ \\
\hline Euro & & & . & 10.515 & 12.652 & 11.660 & 11.858 & 13.760 & 15.432 & 13.510 & 11.956 & 11.739 & 12.810 & 16.821 & 15.133 & $15.069,67$ \\
\hline Pound sterling Inggris & 14.299 & 15.080 & 14.334 & 15.076 & 17.888 & 16.942 & 17.697 & 18.804 & 15.803 & 15.114 & 13.894 & 13.969 & 15.579 & 20.097 & 19.370 & $20.451,11$ \\
\hline Dollar Hongkong & 1.230 & 1.333 & 1.146 & 1.090 & 1.195 & 1.268 & 1.160 & 1.208 & 1.413 & 1.212 & 1.155 & 1.167 & 1.247 & 1.572 & 1.604 & $1.779,83$ \\
\hline Yen lepang & & & & & 9.042 & 8.342 & 7.580 & 8.307 & & 102 & 110 & 117 & 112 & 116 & 104 & 114,52 \\
\hline Ringgit Malaysia & 2.525 & 2.736 & 2.353 & 2.228 & 2.445 & 2.601 & 2.554 & 2.828 & 3.153 & 2.747 & 2.916 & 2.853 & 3.160 & 3.708 & 3.562 & $3.209,65$ \\
\hline Dollar Singapura & & & & & 5.686 & 5.907 & 5.879 & 6.502 & 7.607 & 6.699 & 6.981 & 6.974 & 7.907 & 9.628 & 9.422 & $9.751,19$ \\
\hline Dollar Amerika & 9.595 & 10.400 & 8.940 & 8.465 & 9.290 & 9.830 & 9.020 & 9.419 & 10.950 & 9.400 & 8.991 & $9.06 \mathrm{~B}$ & 9.670 & 12.189 & 12.440 & 13.795 \\
\hline Emas $^{1}$ & 71.875 & 80.000 & 85.000 & 100.000 & 100.000 & 140.000 & 165.000 & 206.667 & 250.000 & 300.000 & 360.000 & 450.000 & 460.000 & 470.000 & 478.402 & \\
\hline Gulden Belanda & 4.044 & 4.169 & & & & & & & & & & & & & & \\
\hline
\end{tabular}

Subjek, Subject

("Kurs Tengah Beberapa Mata Uang Asing Terhadap Rupiah di Bank Indonesia dan Harga Emas di Jakarta"," "Selected Foreign Exchange Middle Rates Against Rupiah at Bank Indonesia and Prices of Gold in Jakarta ")

Keterangan
Sumber Data dari Bank Indonesia

Dutaer Emas Merupakan Data dari Badan Pusat Statistil

Data Yen Jepang untuk Tahun 2008 sampai 2011 Merupakan Angka Diperbail

Tautan Sumber: http://www.bps.go.id/LinkTableDinamis/view/id/952

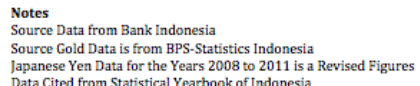

Figure 5. Middle rate of several foreign currencies against rupiah in the period of 2000-2015

This number clearly gives the reality Merry Riana as a result of her hard work. Meanwhile, this figure is a dream for most readers. Thus, it is obvious that the title of the book "Mimpi Sejuta Dolar" makes the reader inspired people to have good financial condition, just like what happened to Merry Riana. Surely, this fantastic number is shown as the title of the book to show the reader that even ordinary people can earn big income.

The success of Merry Riana is inseparable from her thoughts on success. The positive thoughts are depicted by the author, as illustrated by the phrase, "Gempuran keprihatinan itu berhasil membangunkan sel-sel keberanianku dan menggugah kepekaanku dengan lancar, aku bahkan telah berpikir bagaimana caranya agar kemiskinan ini tidak menjadi bingkai abadi dalam hidupku (The fierce-concern has succeeded in awakening my courage cells and arousing my sensibilities smoothly, I have even wondered how this poverty does not become an eternal frame in my life)" ( Endah, p.8, 10).

It is also illustrated in $\mathrm{Ng}$ (p.80), "Lihatlah ke dalam yang tak terlihat. Tembuslah di jarak terjauh kekelaman hati. Bukalah pikiran seluas-luasnya. Itu adalah bekal untuk menjadi pebisnis yang andal (Take a look into the invisible. Break through at the farthest distance of gloom. Open your mind as wide as possible. That is the provision to be a reliable businessman)." This sentence is written as one of the motivation words for someone who is reluctant to dream and work hard to achieve his/her dream. This motivation is given to the readers so as they do not easily discourage but keep to strive as hard as it is shown through the story of her life.

In the context of denotation, these two biographies show the words or phrases that indicate motivation for the reader. This shows that Merry Riana surely wants to be depicted as a motivator for the readers.

In MSD book, Endah shows the testimony of Alva Tjenderasa, Merry Riana's husband. "Sudah jelas, bahwa pada waktu saya bertemu Ria untuk yang pertama kalinya, saya tertarik dengan kecantikannya. Di awal masa berpacaran, saya mulai tahu bahwa ternyata Ria bukan hanya cantik di luarnya saja. Ria mempunyai hati yang besar dan kepribadian yang sangat positif (It's obvious that when I met Ria for the first time, I was attracted by her beauty. At the beginning of our dating, I began to know that Ria has not only outer beauty but also a big heart and a very positive personality)"(Endah, p. 350). This illustrates Merry Riana's personality is filled with hard work.

The story of her failure is also presented in this book, but it still reflects a strong determination to achieve success. "Setelah ratusan penolakan itu, aku semakin terlatih berbicara, bersikap dan bertingkah laku (After hundreds of rejections, I increasingly trained to speak, act and behave)" (Ng, p. 41). As a motivator, it is told that Merry Riana also experiences failure in pursuing her success. However, behind the failure, there is a 
strong determination to reach her dream. On page 85, it is also mentioned, "Ingatlah, kegagalan adalah sebuah feedback (Remember, failure is a feedback)."

The existence of God is enough to be invoked by the author in describing the success of Merry Riana in her work up to she earns more than a million dollars, and her recognition as a motivator. This is written by Endah ( $p$ 12),

"Aku menjadi Merry Riana, anak muda berpenghasilan lebih dari 1 juta dolar, dalam usia 26 tahun. ... Bukan hanya itu, keberadaanku sebagai anak muda yang dianggap sukses di Singapura, telah membawaku pada kepercayaan dan pengakuan sebagai seorang motivator. ... Bukan main. Tuhan begitu bersenyawa dalam langkah-langkahku (I became Merry Riana, a youth earning over 1 million dollars, at the age of 26. ... Besides, my existence as a youth who is considered successful in Singapore, has led me to trust and recognition as a motivator. ... Unbelieveable. God accompanies me and he is so inseparable in my steps)."

Similarly in $\mathrm{Ng}$ (p.27), it is written, "Kuserahkan semuanya ke tangan Tuhan. Aku yakin Dia akan memberikan jalan (I give everything to the God. I'm sure He will give the way)."

On page 2 (MDS), it tells, “Akan tetapi Tuhan begitu baik, ....(But God is so good, ...)”. Similarly in the LSS, Clara Ng also drew the phrase " Tuhan akan bersama orang-orang yang mau menolong dirinya sendiri; tapi aku yakin, Tuhan juga akan selalu bersama orang-orang yang bukan hanya menolong dirinya sendiri, tapi juga orang lain (God will be with those who help themselves; but I'm sure God will always be with people who not only help themselves, but also others)"(p.9).

In several examples above, it seems that Merry Riana is a figure who is very dependent on God. On her Twitter account dated September 13, 2017, Merry Riana shows her dependence on God.

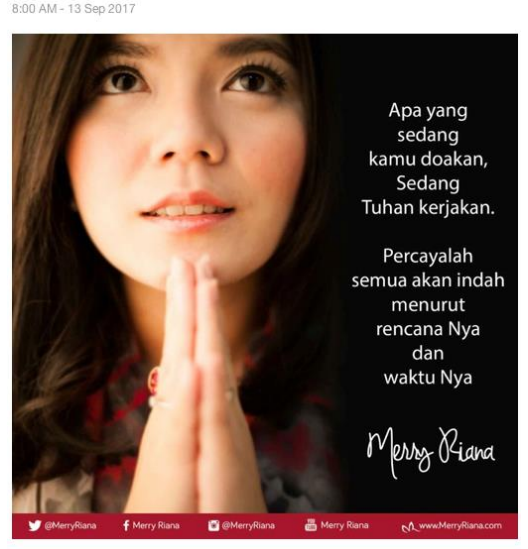

Figure 6. One of the posts on the Merry Riana official twitter account

As a motivator, Merry Riana is also shown that she cannot work alone. She desperately needs Alva, her best friend as well as her husband, become her support in terms of designing strategy and working in the field, even as she begins to despair.

Endah described that on page 108, when Merry Riana has a dialogue with Alva about earning big money. It mentions, "Bersama Alva, aku selalu mendapatkan "rumus" atas segala yang kulakukan (Together with Alva, I always get the "formula" for everything I do)." Then, on page 216: "Alva menyentuh tanganku... Alva menghibur (Alva touched my hand ... Alva comforted me)."

$\mathrm{Ng}$ showed the same thing on page 17:

Alva memandangku. "Tapi, tidak mudah bukan berarti tidak dapat dikerjakan lho." 
(Alva looked at me. "But, difficult does not mean it cannot be done)."

“Apakah aku bisa melakukannya?” tanyaku ragu.

("Can I do it?" I asked doubtfully.)

“Bagaimana kamu tahu kamu bisa melakukannya atau tidak kalau kamu tidak pernah mencoba?” Alva malah bertanya balik kepadaku.

("How do you know you can do it or not if you never try?" Alva even asked me back.)

Perkataan Alva membuatku bergairah, tergugah.

(Alva's words made me excited, intrigued.)

$\mathrm{Ng}$ showed more how Alva gives full support to Merry Riana as written on p. 100, "Jangan menyerah," bisik Alva. "Aku mencintaimu. Aku akan selalu mendukungmu (Do not give up," Alva whispered. "I love you. I will always support you)." Then on p. 101, "Yang terkuat menopang tubuh kita saat kita terjerembap adalah rasa cinta. Inilah sumber inspirasi dan motivasi yang terbesar The strongest support for our bodies when we fall is love. This is the greatest source of inspiration and motivation)." Next, it is told that, love meant here could be love for parents, love for soul mate, love for child. However, at the end of the chapter on page 102, the author asserts that the love here meant is love for Alva. "Aku ingat kata-kata Alva, "Aku mencintaimu." Itu sumber kekuatanku (I remember Alva's words," I love you. "That's the source of my strength)." This shows that Merry Riana is described as having a dependence on Alva as a support in her life.

On page 169, Merry Riana is depicted praying after she is tired and almost desperate. It is Alva who leads the prayer so that God gives them strength.

Several sections in this book show clearly how Merry Riana needs Alva to encourage her, even motivate her. Indeed Alva is not on the front line, but the success of Merry Riana cannot be separated from the presence of Alva, her best friend as well as her husband. There is an idiom says, there is a great woman behind the successful man. However, in the texts of these two biographies show behind the success of a well-known female motivator, there is an unknown male motivator. There is still a woman's dependence on men in Merry Riana's biographies.

\section{Conclusion}

There are three things that are found related to research conducted by Roland Barthes's semiotic analysis method.

First, Merry Riana is described to have a strong character in an effort to reach the best for her future. That is not unprecitable because Marry Riana is a motivator. Second, Merry Riana is a motivator who is close to God. Third, Merry Riana is a motivator who has a close relationship with her husband.

The two biographies of female motivator written by female writers seem to be unable to break free from the concept of women that is embedded in society, which is despite appearing confident, women are still dependent on men. In this case, patriarchal ideology still appears in the biographies of Merry Riana although both books are written by female authors.

\section{References}

Asthararianty dan Lesmana, F. 2017. Hermeneutics Studies on Representation of Merry Riana on Her Biography Cover Design. https://www.atlantis-press.com/proceedings/bcm-17/25892179 
Bappenas. 2015. Kurs Tengah Beberapa Mata Uang Asing Terhadap Rupiah di Bank Indonesia dan Harga Emas di Jakarta (rupiah), 2000-2015. Date of Access: 08/03/2018. https://www.bappenas.go.id/download.php?id=13137?id=13137.

Baran, Stanley. J. 2012. Pengantar Komunikasi Massa: Melek Media dan Budaya Jilid 1 Edisi 5. Jakarta: Penerbit Erlangga

Danesi, Marcel. 2010. Pengantar Memahami Semiotika Media. Yogyakarta: Jalasutra Komunikasi

Dewi, Alit Kumala. Semiotika, bagian I. Diakses dari http://repo.isi-dps.ac.id/464/1/469-1617-1-PB.pdf, pada 27 November 2016

Dewi, Marsinta. 2013. Penerapan Metode Jigsaw II Dalam Pembelajaran Membaca Teks Biografi (Penelitian Eksperimen Semu pada Siswa Kelas XI SMA Pasundan 2 Bandung Tahun Ajaran 2012/2013). Jakarta: Universitas Pendidikan Indonesia. Diakses dari http://repository.upi.edu/2085/4/S_IND_0907458_Chapter1.pdf, pada 27 November 2016

Hidayat, Marifka Wahyu. 2014. Analisis Semiotika Foto pada Buku Jakarta Estetika Banal karya Erik Prasetya. Diakses

http://repository.uinjkt.ac.id/dspace/bitstream/123456789/27362/1/MARIFKA\%20WAHYU\%20HIDAYATFDK.pdf, pada 27 November 2016

Iskan, Dahlan. 2012. Tidak Ada yang Tidak Bisa. Jakarta: PT. Elex Media Komputindo

Marizal, V. 2012. Mercedes Benz. Simbol Kemakmuran dari Jerman. TribunJogja.com, 27 Oktober. Date of Access: 06/03/2018. http://jogja.tribunnews.com/2012/10/27/mercedes-benz-simbol-kemakmuran-dari-jerman

Moleong, Lexy. 2012. Metodologi Penelitian Kualitatif edisi Revisi. Bandung: Remaja Rosdakarya

Noor, Juliansyah. 2011. Metodologi Penelitian. Jakarta: Kencana

Raharjo, Mudjia. 2008. Dasar-Dasar Hermenutika, Antara Intensionalisme \& Gadamerian. Jogjakarta : Ar-ruzz Media.

Riana, Merry. Date of Access: 08/03/2018. https://mobile.twitter.com/MerryRiana/status/907982216776601600

Riswandi. 2013. Psikologi Komunikasi. Yogyakarta: Graha Ilmu

Sobur, Alex. 2009. Semiotika Komunikasi. Bandung: Remaja Rosdakarya

Sumaryono, E. 1999. Hermenutik, Sebuah Metode Filsafat. Jogjakarta: Kanisius.

Suwarno, Wiji. 2014. Perpustakaan dan Buku: Wacana Penulisan dan Penerbitan. Jogjakarta: Ar-ruzz Media Vivian, John. (2008) : Teori Komunikasi Massa. Edisi ke-8. Jakarta: Kencana.

Vujicic, Nick. 2010. Life Without Limits. Colorado: WaterBrook Press

Walker. A. John. 2010. Desain, Sejarah, Budaya, Sebuah Pengantar Komprehensif. Jogjakarta: Jalasutra. 